\title{
KIPRAH HERITAGE SEBAGAI SIMBOLISASI CITY BRANDING DAN \\ GOOD GOVERNANCE : Studi Semiotika Komunikasi Publik pada Kampoeng Heritage Kajoetangan sebagai Bagian City Branding Kota Malang
}

\author{
Arif Budi Prasetya \\ Universitas Brawijaya Malang \\ arif.prasetya@ub.ac.id \\ Widya Pujarama \\ Universitas Brawijaya Malang \\ mncprwidya@ub.ac.id
}

\begin{abstract}
ABSTRAK
Konsep heritage dan City Branding memiliki relasi yang sangat kuat. Keberadaan heritage yang dimiliki Kota Malang telah mampu membentuk sebuah brand image yang positif. Aspek heritage ini juga yang dapat meningkatkan kualitas good governance di wilayah Kota Malang. Aspek heritage pula yang dapat memberikan dampak positif untuk tagline yang dimiliki Kota Malang yaitu "Beautiful Malang”. Dengan menggunakan konsep semiotika dan kajian komunikasi public, dapat diketahui bahwa aspek heritage Kota Malang melalui Kampoeng Heritage Kajoetangan telah meningkatkan image Kota Malang dan membentuk good governance.
\end{abstract}

Kata Kunci : Heritage, City Branding, Kota Malang, Good Governance

\begin{abstract}
The concept of heritage and City Branding has a very strong relationship. The existence of heritage owned by Malang City has been able to form a positive brand image. This aspect of heritage can also improve the quality of good governance in the Malang City area. Heritage aspects also can give a positive impact to the tagline owned by Malang, namely "Beautiful Malang". By using the concept of semiotics and public communication studies, it can be seen that the aspects of the heritage of Malang City through Kajoetangan Heritage Kampoeng have improved the image of Malang City and formed good governance.
\end{abstract}

Keywords: Heritage, City Branding, Malang City, Good Governance 


\section{PENDAHULUAN}

Good governance secara sederhana tidak hanya dimaknai sebagai pemerintahan yang baik, tapi juga didefinisikan sebagai usaha untuk mewujudkan pemerintahan yang baik, keterbukaan informasi, penegakan hukum, dan usaha maksimal untuk melawan korupsi (Rothstein dan Teorell, 2012: 13). Hal itu menunjukkan bahwa good governance berhubungan erat dengan semua aktivitas pemerintah untuk menjalin komunikasi yang baik dengan masyarakat. Karena masyarakat bisa memberikan informasi, dan aspirasi yang baik kepada pemerintah demi tercapainya bentuk pemerintahan yang baik. Karena itu good governance bisa diwujudkan bersama-sama dengan proses demokrasi yang baik, karena demokrasi memberikan landasan bagi munculnya kebebasan berpendapat bagi semua anggota masyarakat. Dengan demikian demokrasi kemungkinan besar tidak membenarkan sikap memaksakan kehendak, namun lebih banyak mendukung sikap untuk saling menghormati pendapat orang lain, selama pendapat tersebut diberikan serta disampaikan dengan cara yang baik diiringi dengan sikap saling menghormati. Salah satu usaha untuk mencapai good governance dalam suatu wilayah adalah dengan memperhatikan aspek yang dimiliki wilayah tersebut, salah satunya adalah heritage.

Berbicara mengenai heritage (situs warisan budaya) maka kita akan berada dalam tataran simbolisasi dan saksi sejarah terhadap sebuah wilayah. Dalam kaitannya sebagai bentuk usaha pelestarian maupun konsep symbol mengenai kultur budaya tertentu. Dalam perkembangannya, heritage menjadi salah satu bagian pembentukan citra suatu wilayah, atau yang biasa kita kenal dengan sebutan city branding. Pemahaman mengenai city branding tidak hanya sebatas pembentukan citra suatu wilayah saja. Namun juga berbicara mengenai bagaimana masyarakat mengenal wilayah tersebut. Tulisan kali ini akan berfokus pada city branding Kota Malang melalui heritage yang dimiliki sekaligus berbicara tentang kiprah heritage tersebut.

Heritage yang berada di Kota Malang, berdasarkan data yang dimiliki oleh pemerintah Kota Malang, jumlahnya cukup banyak, dan tersebar di seluruh wilayah Kota Malang. Namun kali ini, pembahasan akan berfokus pada salah satu wilayah yang sedang gencar dikerjakan oleh pemerintah Kota Malang untuk menjadi salah satu heritage yang berfungsi sebagai destinasi wisata, sekaligus menjadi bagian dari city branding Kota Malang, yaitu Kampoeng Heritage Kajoetangan (baca : kampung Heritage Kayutangan). Sebagai wilayah yang berusia cukup tua di Kota Malang, Kayutangan menyimpan beberapa warisan atau peninggalan sejarah dan budaya 
khas Kota Malang sejak zaman colonial Belanda. Bangunan rumah dan sejumlah bangunan lain menjadi saksi interaksi dan budaya masyarakat Kota Malang saat itu.

Brand resmi dari kota Malang adalah "Beautiful Malang” (Pemerintah Kota Malang, n.d) melalui simbol bunga, yang juga merangkum brand image kota Malang sebagai kota yang sejuk dan penuh bunga dan disebut oleh warga sebagai Malang Kota Bunga (Makobu). Sebutan Makobu masih relevan ketika kota Batu masih masuk ke dalam kota admistratif Malang, meski hingga sekarang jargon Makobu masih sering terdengar disebut oleh warga sebagai brand image dari kota Malang. Selain brand resmi, Malang memiliki sebutan sebagai kota pendidikan sejak tahun 1930 (Widodo, 2006), dan sejak tahun 2016, melalui momentum Indonesia Creative Cities Conference (ICCC), Pemerintah kota Malang menggunakan istilah kota pendidikan internasional sebagai bagian dari brand kota Malang (Bidang Informasi Publik Pemkot Malang, 2016).

Brand-brand yang muncul dan mendefinisikan kota Malang tersebut masih sering kali disebutkan karena brand dari sebuah kota bisa berasal baik dari strategi pemerintah kota dengan tingkat kesengajaan tinggi maupun dari proses komunikasi yang dilakukan oleh warga atau pengunjung kota Malang. Braun, Kavaratzis dan Zenker (2013) menjelaskan bahwa warga suatu kota merupakan bagian integral dari place brand melalui perilaku dan karakteristik yang melekat pada individu-individu secara kolektif.

Dengan menjadikan heritage sebagai bagian dari pembentukan citra Kota Malang, terdapat beberapa aspek yang menarik untuk dikaji dalam ranah empiris akademis. Kita bisa mengetahui bahwa Image sebuah kota bisa berasal dari upaya baik sengaja maupun tidak disengaja dari pemerintah kota tersebut. Upaya sengaja untuk meningkatkan reputasi dan image dari sebuah kota disebut dengan city branding, yang merupakan "sebuah strategi untuk meningkatkan keuntungan kompetitif, dengan menyediakan kota-kota dengan gambaran tertentu yang bersumber dari nilai ekonomis, signifikansi politik dan budaya, serta perkembangan sosial-ekonomi” dari kota tersebut (Popescu, 2012). Braun (2012) menyebutkan bahwa city branding merupakan salah satu bentuk dari urban governance, dimana atmosfir politik berpengaruh terhadap brand dari kota yang ada.

Dengan mengedepankan keunggulan yang dimilikinya serta meletakkan dasar prinsip mengenai aspek utama Kota Malang melalui tagline "Beautiful Malang", maka konsep heritage 
ini menjadi sejalan dengan tujuan tersebut. Focus utama yang menjadi pokok pembahasan kali ini terkait dengan bagaimana Heritage tersebut memiliki peran dalam simbolisasi city Branding. Konsep komunikasi public yang dikedepankan menjadi landasan kajian empiris yang kemudian secara konseptual dapat dijadikan analisis dalam tulisan ini.

Apabila ditinjau kembali, heritage Kota Malang secara eksplisit menggambarkan realitas sejarah dan budaya Kota Malang. Namun secara implisit dapat diartikan menyampaikan konsep keindahan dan sejalan dengan tagline "Beautiful Malang". Konsep komunikasi public yang disajikan juga menjadi perhatian yang menarik untuk kemudian dianalisis. Dengan menggunakan studi eksplorasi mengenai komunikasi public pada heritage Kota Malang, maka simbolisasi peran heritage pada City Branding Kota Malang dapat diketahui secara empiris dan komprehensif.

\section{KAJIAN TEORI}

Kajian teoritis yang digunakan oleh peneliti dalam tulisan ini berangkat dari tradisi semiotika, yaitu kajian mengenai konsep tanda. Semiotik menjadi salah satu kajian yang bahkan menjadi tradisi dalam teori komunikasi. Tradisi semiotik terdiri atas sekumpulan teori tentang bagaimana tanda-tanda merepresentasikan benda, ide, keadaan, situasi, perasaan dan kondisi di luar tanda-tanda itu sendiri. (Littlejohn, 2009 : 53). Semiotik bertujuan untuk mengetahui maknamakna yang terkandung dalam sebuah tanda atau menafsirkan makna tersebut sehingga diketahui bagaimana komunikator mengkonstruksi pesan. Konsep pemaknaan ini tidak terlepas dari perspektif atau nilai-nilai ideologis tertentu serta konsep kultural yang menjadi ranah pemikiran masyarakat di mana simbol tersebut diciptakan. Kode kultural yang menjadi salah satu faktor konstruksi makna dalam sebuah simbol menjadi aspek yang penting untuk mengetahui konstruksi pesan dalam tanda tersebut. Konstruksi makna yang terbentuk inilah yang kemudian menjadi dasar terbentuknya ideologi dalam sebuah tanda. Sebagai salah satu kajian pemikiran dalam cultural studies, semiotik tentunya melihat bagaimana budaya menjadi landasan pemikiran dari pembentukan makna dalam suatu tanda.

Berkaitan dengan itu, maka perlu untuk diselaraskan terlebih dahulu mengenai relasi antara heritage dengan tradisi semiotika tersebut. Konstruksi yang terbangun dalam sebuah diskusi mengenai relasi antar tanda tidak hanya berangkat dari makna apa yang kemudian muncul. Namun 
juga bisa merupakan struktur tanda yang terbentuk disertai dengan adanya budaya dan keyakinan yang diusung oleh masyarakat pengguna tanda. Dalam hal ini, tradisi semiotika merupakan tradisi yang bersumber dari paradigm konstruktivis. Aspek teks yang tersaji dalam tradisi semiotika kemudian menjadi dasar sebagai rujukan yang akan diamati. Sehingga makna yang terkandung akan dapat diketahui dengan jelas, walaupun subjektifitas pembaca teks masih dominan.

Dalam kaitan ini, perlu dicatat bahwa dalam penggunaan metafora dalam teks membuka kemungkinan besar pada penafsiran oleh pembaca. (Hoed, 2014 : 173). Artinya adalah kita akan dihadapkan pada sejumlah besar penafsiran yang ada kalanya berangkat dari hanya satu symbol saja. Hal ini membuktikan bahwa pemaknaan terhadap suatu tanda bersifat general dan abstrak. Tidak bisa kemudian kita memaksakan kehendak untuk melakukan generalisir terhadap makna tanda tersebut.

Berbicara mengenai konsep kajian semiotika, yang digunakan dalam tulisan kali ini merupakan semiotika model analisis Roland Barthes. Pemikiran semiotik Barthes bisa dikatakan paling banyak digunakan dalam penelitian. Konsep pemikiran Barthes terhadap semiotik terkenal dengan konsep mythologies atau mitos. Sebagai penerus dari pemikiran Saussure, Roland Barthes menekankan interaksi antara teks dengan pengalaman personal dan kultural penggunanya, interaksi antara konvensi dalam teks dengan konvensi yang dialami dan diharapkan oleh penggunanya. (Kriyantono, 2007 : 268). Konsep pemikiran Barthes yang operasional ini dikenal dengan Tatanan Pertandaan (Order of Signification). Secara sederhana, kajian semiotik Barthes bisa dijabarkan sebagai berikut :

\section{Denotasi}

Denotasi merupakan makna sesungguhnya, atau sebuah fenomena yang tampak dengan panca indera, atau bisa juga disebut deskripsi dasar. Contohnya adalah Coca-Cola merupakan minuman soda yang diproduksi oleh PT. Coca-Cola Company, dengan warna kecoklatan dan kaleng berwarna merah. 


\section{Konotasi}

Konotasi merupakan makna-makna kultural yang muncul atau bisa juga disebut makna yang muncul karena adanya konstruksi budaya sehingga ada sebuah pergeseran, tetapi tetap melekat pada simbol atau tanda tersebut. Contoh adalah Coca-Cola merupakan minuman yang identik dengan budaya modern, di mana Coca-Cola menjadi salah satu produk modern dan cenderung kapitalis. Dengan mengkonsumsi Coca-Cola, seorang individu akan tampak modern dan bisa dikatakan memiliki pemikiran budaya populer.

Dua aspek kajian dari Barthes di atas merupakan kajian utama dalam meneliti mengenai semiotik. Kemudian Barthes juga menyertakan aspek mitos, yaitu di mana ketika aspek konotasi menjadi pemikiran populer di masyarakat, maka mitos telah terbentuk terhadap tanda tersebut. Pemikiran Barthes inilah yang dianggap paling operasional sehingga sering digunakan dalam penelitian. Berikut adalah konsep pemikiran Barthes dalam bentuk bagan :

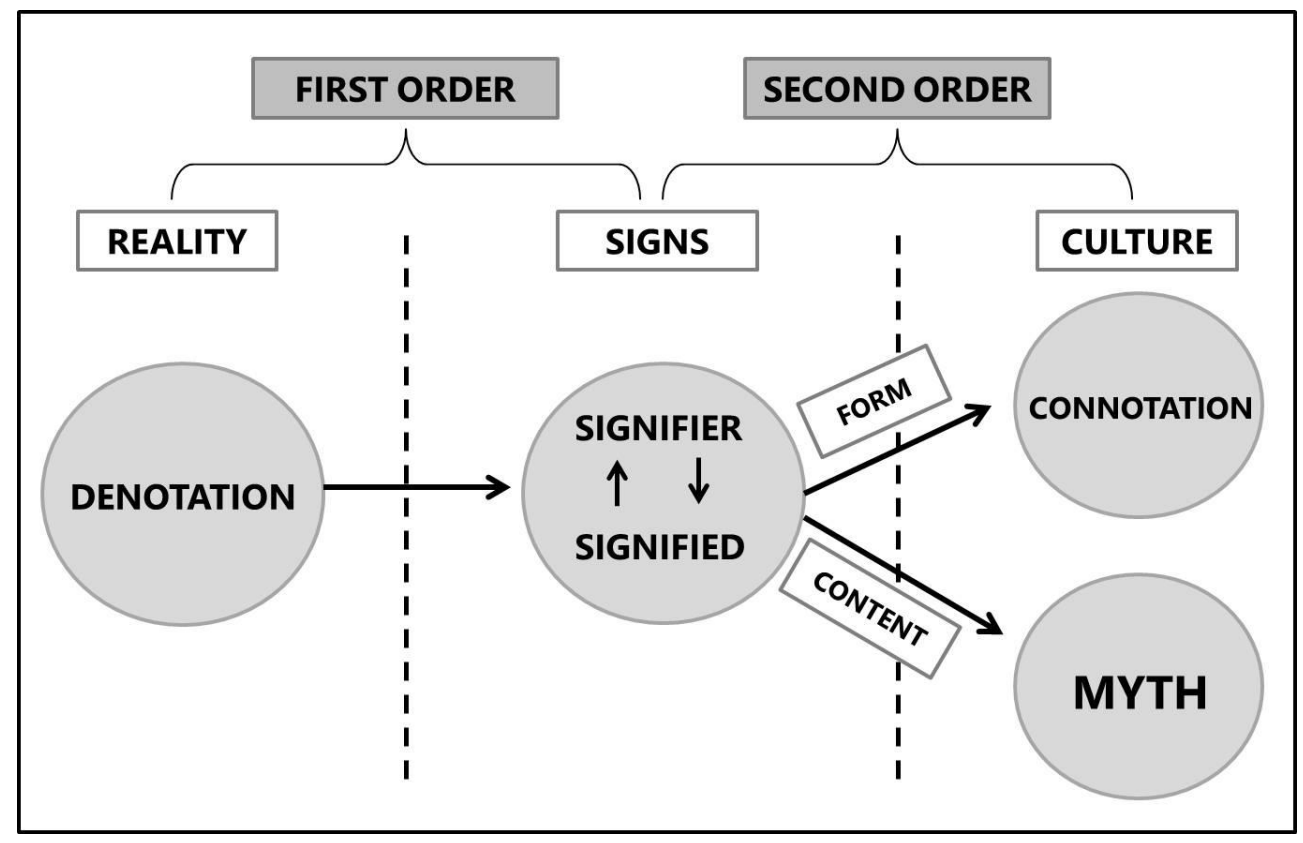

Gambar 1. Two Order of Signification Roland Barthes 


\section{HERITAGE SEBAGAI SIMBOL CITY BRANDING}

Sebagai bagian dari pembentukan brand image Kota Malang, wilayah Kayutangan menjadi factor utama untuk kemudian bisa memberikan warna tersendiri. Dengan penamaan Kampoeng Heritage Kajoetangan, berbagai macam simbolisasi Kota Malang dapat diketahui. Sebagai bagian dari aspek pembentuk image Kota Malang yang memberikan sajian sejarah dan budaya, heritage tersebut mampu membentuk citra yang positif. Selain itu aspek pembentuk good governance juga dapat direalisasikan. Selama ini, aspek heritage Kota Malang kurang mendapatkan perhatian dari masyarakat. Namun dengan usaha pemerintah yang dibantu oleh berbagai elemen masyarakat, maka dapat tercipta wahana baru yaitu heritage Kota Malang.

Sebagai bagian dari symbol Kota Malang saat ini, wilayah Kayutangan merupakan wilayah yang memiliki image sebagai wilayah yang berusia cukup tua. Dalam istilah lazim di masyarakat dikenal dengan sebutan "kotalama" atau "kota tua". Hal ini wajar karena di wilayah Kayutangan terdapat banyak bangunan-bangunan bersejarah, yang dimiliki oleh perseorangan. Apabila dikaitkan dengan kajian empiris, wilayah Kayutangan merupakan simbolisasi yang berimplikasi kepada cakupan city branding Kota Malang. Sehingga wilayah Kayutangan sekaligus merepresentasikan Kota Malang melalui keindahan sejarahnya, yang sejalan dengan konsep "Beautiful Malang".

Perhatikan gambar ini :

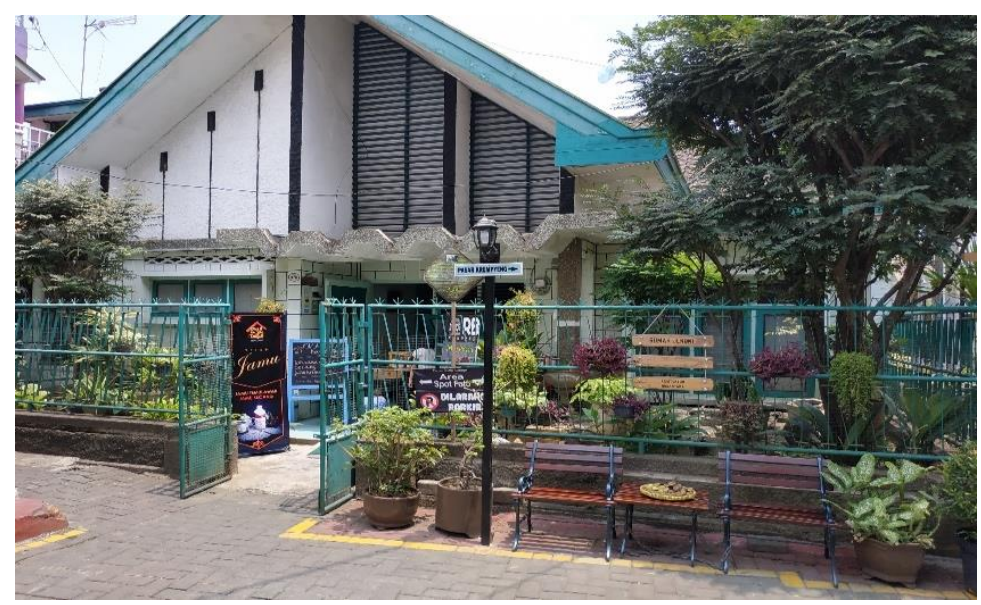

Gambar 2. Salah satu rumah tua di wilayah Kampoeng Heritage

Sumber : dokumentasi peneliti 
Gambar di atas menyajikan sebuah konsep heritage yang terdapat di Kampoeng Heritage Kajoetangan. Terkait dengan hal tersebut, kita bisa melihat sebuah struktur bangunan yang memiliki nilai sejarah. Dengan memperhatikan tiap bangunan serta kiprah heritage dalama membentuk city branding Kota Malang, bisa dilihat bahwa relasi antara dua aspek tersebut dapat diketahui. Foto tersebut sekaligus menunjukkan bahwa wilayah Kampoeng Heritage Kayoetangan di Kota Malang dapat memiliki kemampuan dalam membentuk strategi city branding.

\section{PEMBAHASAN}

Berdasarkan kajian di atas dapat diambil temuan data sebagai berikut :

Heritage memiliki Peran dalam Pembentukan City Branding. Aspek diketahui setelah melakukan analisis terhadap sejumlah foto dan temuan data di lapangan. Konsep komunikasi public heritage Kota Malang menjadi penentu. Selain itu, dari foto juga dapat disimpulkan bahwa Kampoeng Heritage Kajoetangan menjadi salah satu ciri khas yang dimiliki oleh Kota Malang. Berikut adalah foto dan analisis data :

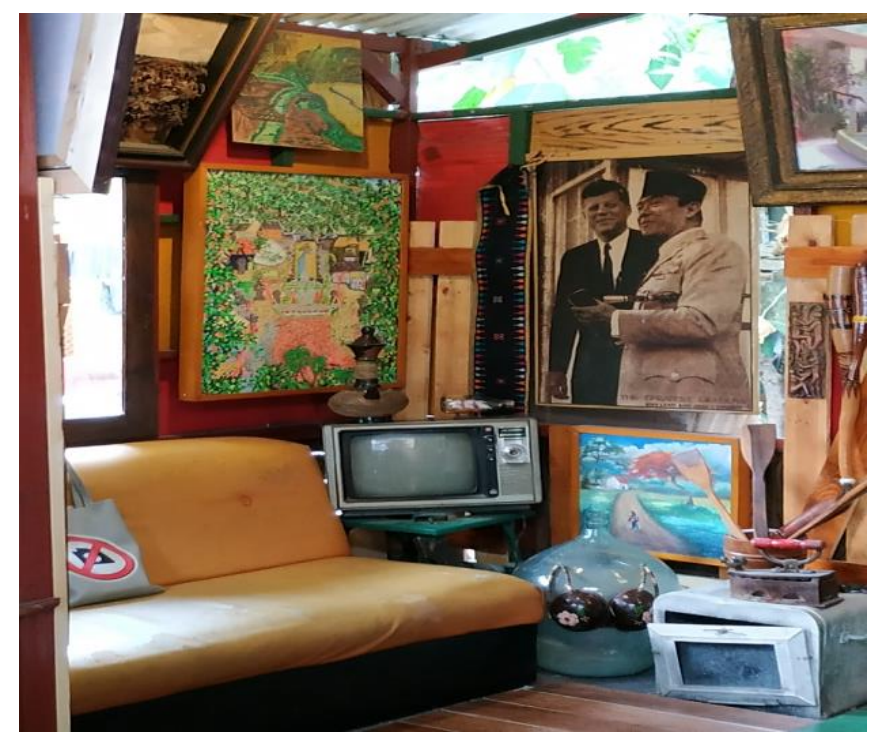

Gambar 3. Foto salah satu ruangan galeri di Kampoeng Heritage Kajoetangan Sumber : dokumentasi peneliti.

Melalui analisis denotasi dan konotasi Roland Barthes terhadap gambar diatas, diketahui bahwa sudut ruangan galeri tersebut memiliki simbolisasi heritage. Keberadaan foto presiden pertama 
Republik Indonesia, Soekarno bersama mantan presiden Amerika Serikat, John F Kennedy, memberikan simbolisasi sejarah yang kuat. Selain itu, keberadaan atribut lawas seperti televise tabung, lukisan, setrika arang dan nuansa bangunan kayu, memberikan simbolisasi heritage yang semakin komplet.
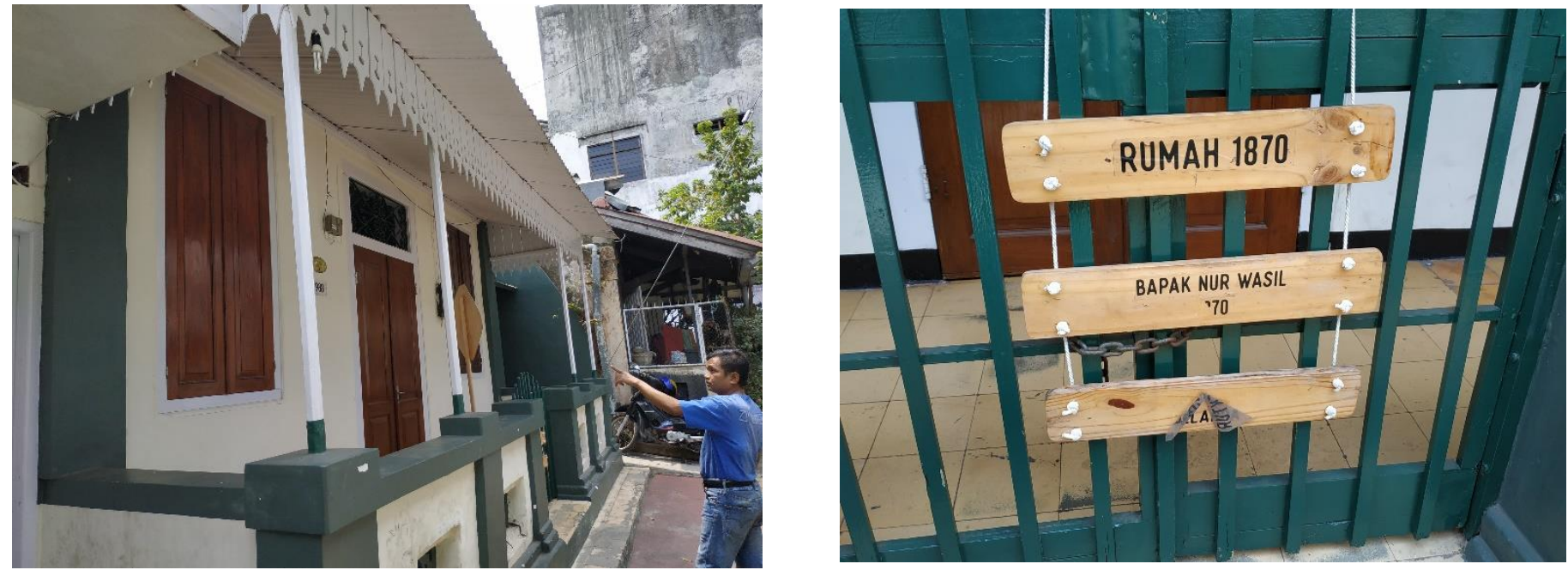

Gambar 4. Foto rumah Bapak Nur Wasil yang dibangun pada tahun 1870

Sumber : dokumentasi peneliti

Foto diatas juga menunjukkan konsep simbolisasi mengenai heritage yang menjadi pembentuk city branding kota Malang. Foto di atas berfokus pada sebuah rumah yang dibangun pada tahun 1870. Penekanan pada aspek tahun dan bentuk rumah menjadi poin penting terbentuknya aspek historis yang menjadi symbol kota Malang sebagai kota sejarah dan penuh keindahan. Konotasi dalam tataran semiotika Roland Barthes juga memiliki aspek yang bermakna bahwa Kampoeng Heritage Kajoetangan melalui bangunan-bangunan bersejarahnya menyimbolkan sebuah keindahan. 
$\underline{\text { Kiprah Heritage sebagai Simbolisasi City Branding.................(Arif B.Prasetya, Widya Pujarama) }}$

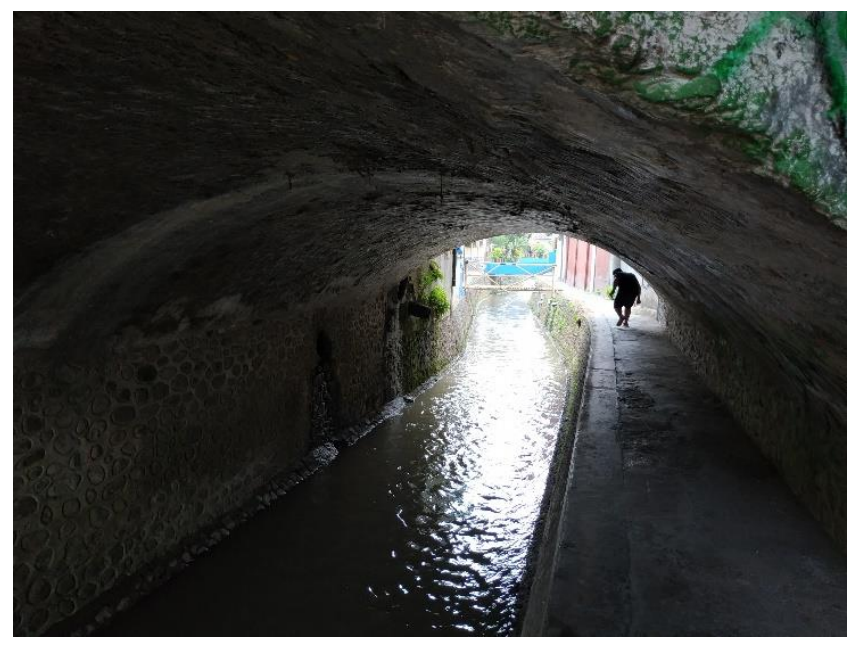

Gambar 5. Terowongan saluran air zaman colonial Belanda Sumber : dokumentasi peneliti

Foto di atas merupakan sebuah terowongan saluran air yang dibangun pada masa colonial penjajahan Belanda. Tidak ada dokumentasi resmi mengenai tahun pembuatannya, namun terowongan tersebut juga menjadi bagian dari Kampoeng Heritage Kajoetangan. Hal ini secara aspek semiotika menandakan bahwa Malang memiliki banyak bangunan bersejarah yang mampu menjadi symbol dan berkaitan langsung dengan aspek City Branding. Keindahan yang disajikan menjadi bukti bahwa sebuah wilayah ketika memiliki banyak bangunan bersejarah akan mampu menciptakan brand image sehingga meningkatkan citra wilayah tersebut.

\section{KESIMPULAN}

Melalui penjabaran diatas dapat diambil kesimpulan bahwa Heritage Kota Malang merupakan aspek penting dalam menciptakan good governance. Pemerintah Kota Malang melalui program Kampoeng Heritage Kajoetangan telah memberikan sebuah program peningkatan kualitas yang berimplikasi langsung kepada terbentuknya brand image Kota Malang. Sehingga melalui konsep heritage ini, Kota Malang akan semakin dikenal masyarakat luas, tidak hanya sebagai Kota Pendidikan, namun juga selaras dengan tagline "Beautiful Malang" melalui keindahan heritage yang dimiliki. 


\section{DAFTAR PUSTAKA}

Braun, E. 2012. "Putting city branding into practice.” Journal of brand management. 19. Pp. 257267. DOI: $10.1057 / \mathrm{bm} .2011 .55$.

Kriyantono, R. 2007. Teknik Praktis Riset Komunikasi. Jakarta: Kencana

Littlejohn, Stephen W, 2009 . Teori Komunikasi Theories of Human Communication edisi 9. Jakarta: Salemba Humanika.

Popescu, A. I. 2012. "Branding cities as educational centres: The role of higher education institutions." Management \& marketing: Challenges for the knowledge society. 7 (3). Pp. 493-512.

Rothstein, B. \& Teorell, J. 2012. Defining and Measuring Quality of Government. dalam Soren Holmberg dan Jan Teorell (editor). Good Government, The Relevance of Political Science: 13-39. Cheltenham: Edward Elgar.

Widodo, D. I. 2006. Malang Tempo Doeloe. Vol 1. Surabaya: Bayumedia Pub. 